\title{
One-stage laparoscopic surgery for left renal cell carcinoma and cecal cancer
}

\author{
Satoshi Tokuda, Hajime Orita, Hiroshi Maekawa, \\ Kentaro Imaizumi, Kazuhiko Fujita, Koichi Sato
}

\begin{abstract}
Introduction: Laparoscopic surgery has been utilized in the fields of gastroenterology, urology and gynecology for the last decade. Colorectal cancer and renal cell carcinoma are becoming more common, and syncronous cases are possible. Laparoscopic surgery for colon cancer and renal cell carcinoma are stylized operations, while the concurrent operation by laparoscopy is rare. In this report, we describe a case of simultaneous laparoscopic surgery for a left renal cell carcinoma and cecal cancer. In this operation, we created new locations for the trocars. Case Report: An 83-year-old man was diagnosed with cecal and left renal cell carcinomas. He was of an advanced age, therefore one-stage surgery with laparoscopy by urologists was chosen by paying attention to the position of the trocars. The total number of trocars was 7 , and the total combined wound length was $12 \mathrm{~cm}$. The operation time was 9 hours 20 minutes. Nevertheless, blood loss was minimal $(30 \mathrm{ml})$, and the postoperative course was uneventful. He was discharged on the 12th hospital day. Conclusion: We experienced concurrent cancer cases and performed the simultaneous operation safely. Simultaneous
\end{abstract}

Satoshi Tokuda1 ${ }^{\text {, Hajime Orita }}{ }^{1}$, Hiroshi Maekawa1 ${ }^{1}$ Kentaro Imaizumi $^{2}$, Kazuhiko Fujita ${ }^{2}$, Koichi Sato ${ }^{1}$

Affiliations: ${ }^{1}$ Department of Surgery, Juntendo Shizuoka Hospital, Shizuoka, Japan; ${ }^{2}$ Department of Urology, Juntendo Shizuoka Hospital, Shizuoka, Japan.

Corresponding Author: Hajime Orita, MD, Department of Surgery, Juntendo Shizuoka Hospital, Shizuoka, Japan, Nagaoka 1129, Izunokuni-shi, Shizuoka-ken, Japan 410-2295, Email: oriori@juntendo.ac.jp

Received: 24 January 2018

Accepted: 15 March 2018

Published: 20 April 2018 laparoscopic surgery for renal cell carcinoma and cecal cancers is feasible and safe in elderly patients.

Keywords: Cecal cancer, Laparoscopic surgery, Renal cell carcinoma

\section{How to cite this article}

Tokuda S, Orita H, Maekawa H, Imaizumi K, Fujita K, Sato K. One-stage laparoscopic surgery for left renal cell carcinoma and cecal cancer. Int J Case Rep Images 2018;9:100908Z01ST2018.

Article ID: 100908Z01ST2018

$$
* * * * * * * * *
$$

doi: 10.5348/100908Zo1ST2018CR

\section{INTRODUCTION}

The skill of laparoscopic surgery is well established and its use is increasing in the fields of gastroenterology, urology and gynecology. With the aging of society, patients who have colorectal cancer (CRC) or renal cell carcinoma (RCC) are becoming more common [1]. Colorectal cancer is estimated at 1.4 million cases in 2012 in the world, [1] and approximately 273,000 new cases of kidney cancer are diagnosed worldwide each year [2]. Given these numbers synchronous cases of CRC and RCC are possible. (0.03-4.85\%) [3, 4]. Patients with urologic cancer are at high risk of getting colorectal cancer later [5]. Laparoscopic surgeries for colon cancer and renal cell carcinomas are individualized operations (the position of trocars, the procedure of operation), while the collaborative operation by laparoscopy is rare.

We report a case in which simultaneous laparoscopic surgery for left renal cell carcinoma and cecal cancer (right 


\section{EDORIUM Journals}

Int J Case Rep Images 2018;9:100908Z01ST2018.

www.ijcasereportsandimages.com

side) was performed. In the operation, we individualized the locations of trocars to achieve minimal invasion for the patient.

\section{CASE REPORT}

An 83-year-old man, presented with bloody stool to a medical check was diagnosed with cecal cancer after colonoscopy (well differentiated carcinoma was diagnosed after biopsy). He came to our hospital for further examination. A physical examination demonstrated the following characteristics: height $156 \mathrm{~cm}$; weight $58 \mathrm{~kg}$; blood pressure $132 / 77 \mathrm{mmHg}$; and pulse rate 82 beats /min. His performance status (PS) was o. A blood test indicated mild anemia (RBC $372 \times 10^{4} / \mu \mathrm{l}, \mathrm{Hgb} 12.7 \mathrm{~g} /$ dl, Hct $38.4 \%$ ); a CA19-9 of $48 \mathrm{U} / \mathrm{ml}$; and a carcinoembryonic antigen (CEA) of $5 \mathrm{ng} / \mathrm{ml}$. Barium enema examination and colonoscopy a showed protruded lesion on the cecum (Figures 1 and 2).

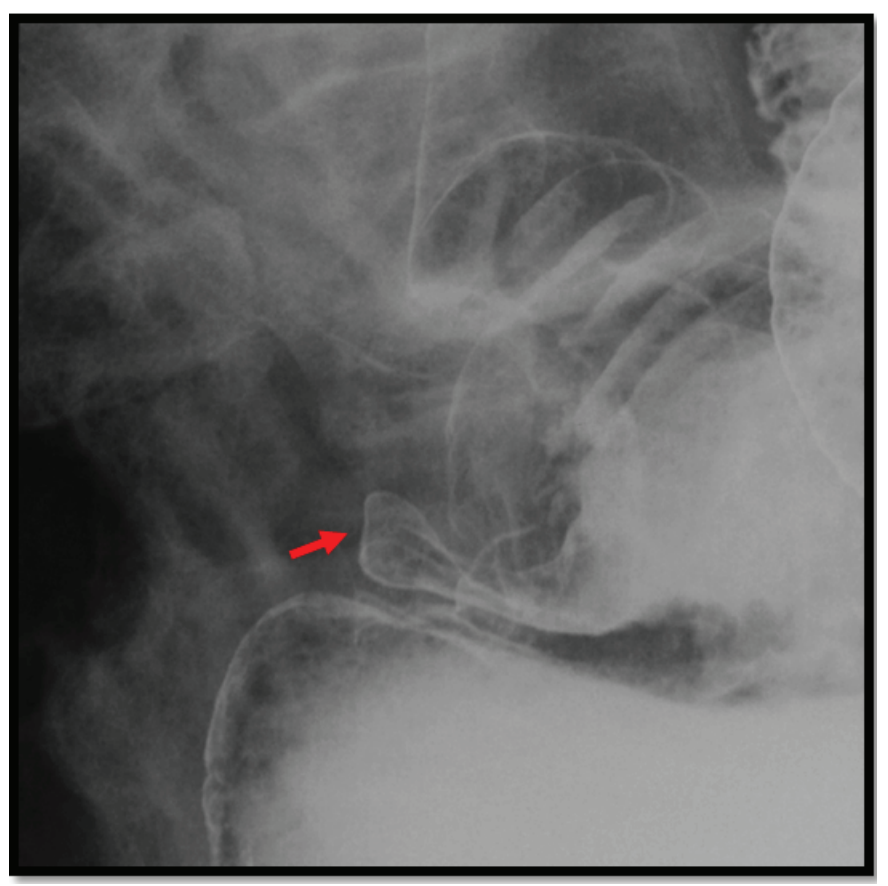

Figure 1: Barium enema examination shows protruded lesion on the cecum and the lesion was suspected to be tumor. There was no lesion on the colon with the exception of cecum.

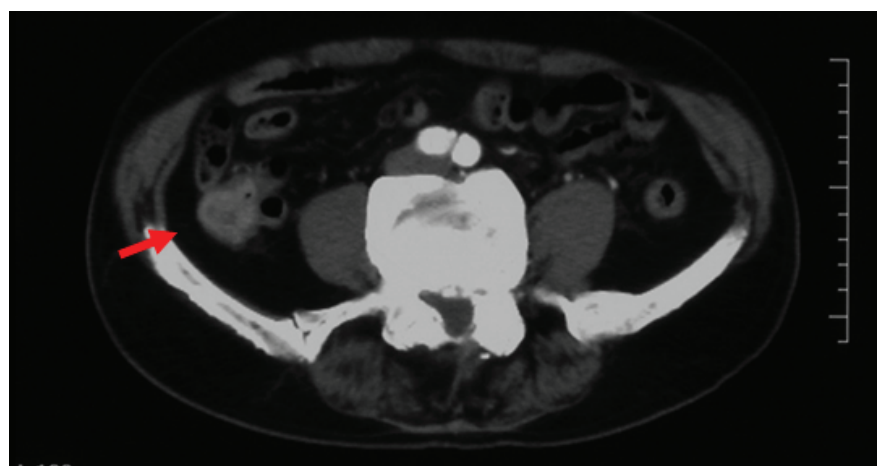

Figure 2: Contrast-enhanced computed tomography illustrated cecum wall thickening with contrast effect.
The computed tomography (CT) scan showed contrast effects on the wall of the cecum. In addition, he had a left renal cell carcinoma, which was unexpected (Figure 3). The carcinoma was enhanced in the arterial phase.

He was of an advanced age (83), therefore, one-stage surgery was chosen in order to minimize complications as we believed that sharing the trocars between surgeons would be less invasive for him. Surgery was performed in collaboration with us (gastrointestinal surgeons) and a team of urologists. We did laparoscopy assisted ileocecal resection with a $\mathrm{D}_{3}$ radical lymph node dissection and laparoscopic nephrectomy.

At first, we did a resection of the cecal cancer. The posture was lithotomy position, head-down and left rotation. Intra-abdominal pressure of $15 \mathrm{mmHg}$ was maintained. The points of the trocars for the cecal operation are $12 \mathrm{~mm}$ at navel for camera, $5 \mathrm{~mm}$ at right subcostal zone, right and left lower abdominal region for forceps and $12 \mathrm{~mm}$ at left subcostal zone for forceps. Next the cecal operation, urologists used two $5 \mathrm{~mm}$ trocars (right subcostal zone and left lower one) and added two $5 \mathrm{~mm}$ trocars at scrobiculuscordis and left subcostal zone (Figure 4).

First of all, we separated the mesentery from the ileo-colic artery and cut the roots of ileo colic artery and veinwith absorbent clips. After that, we clipped andcutthe

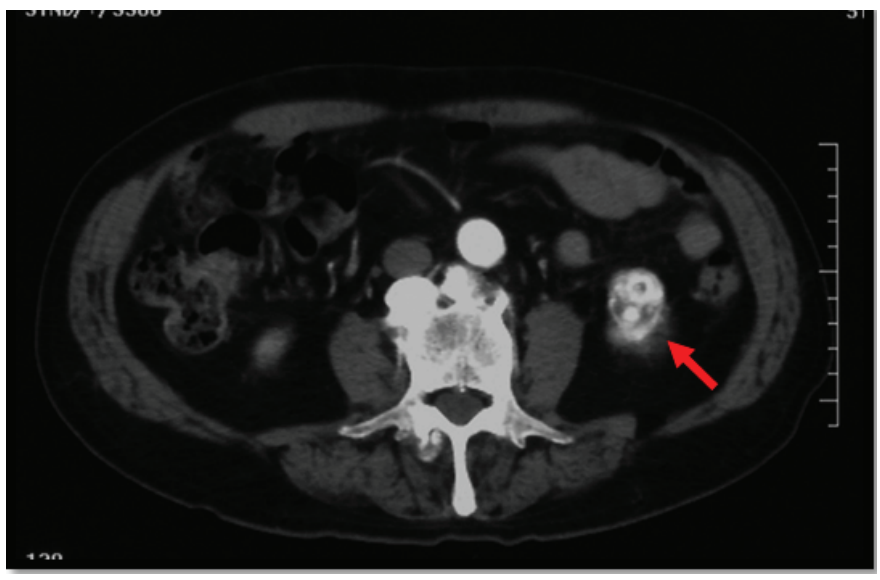

Figure 3: Contrast-enhanced computed tomography reported that he has left renal cell carcinoma.

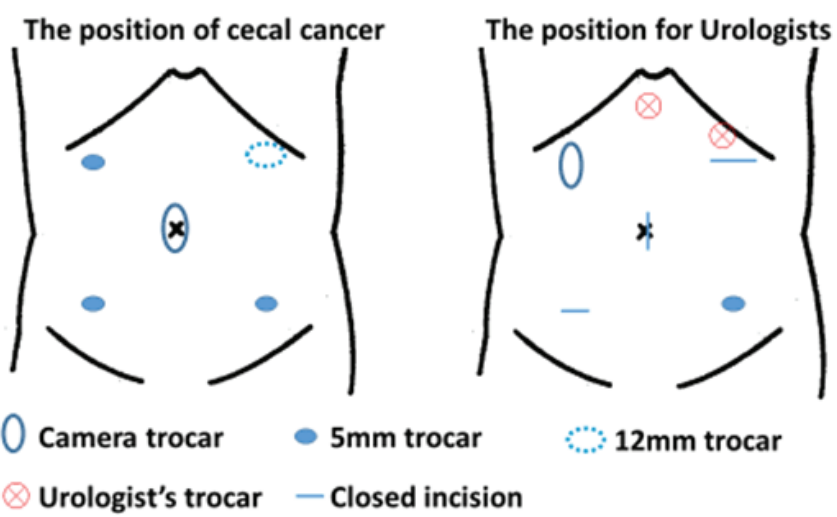

Figure 4: Position of trocars. 


\section{EDORIUM Journals}

accessory right colic vein to avoid post hemorrhage. There was no right colic artery. Instead we found a right branch of the middle colic artery. We then separated the ureter and the testicular blood vessel from mesentery to dorsal. We confirmed duodenum, exfoliated the front of the horizontal portion and second portion, while paying attention to the pancreas. Next we mobilized the mesentery from the outside of the ascending colon up to the hepatic flexure and the omentum in the middle of transverse colon. We extended the navel incision to 5 $\mathrm{cm}$ and brought the ileo-cecum outside of the body. We left $10 \mathrm{~cm}$ proximal and distal margins and resected the colon. We did a functional end-to-end anastomosis (with mechanical extracorporeal anastomosis). After closing the navel, right lower and left subcostal zone incisions, we handed the operation over to the urologists.

We added two $5 \mathrm{~mm}$ trocars at the scrobiculuscordis and left subcostal zones (slightly above our incision). We used the same two $5 \mathrm{~mm}$ trocars (right subcostal zone and left lower one) and changed the position to right lateral. There was a left renal artery and vein. We clipped and cut each one respectively and then exfoliated around the left kidney and removed it from navel incision which was extended (Figure 4). Operation time was 9 hours 20 minutes (colon part was 3 hours 50 minutes) and blood loss was minimal at $30 \mathrm{ml}$. The postoperative course was uneventful, and he was discharged after twelve days. He had no evidence of recurrence at 5-year follow up.

The resected tissue of the cecal cancer was $40 \times 30 \times 10$ $\mathrm{mm}$. One of the ten lymph nodes showed metastasis. All resection margins were free in both procedures. Pathologic classification according to the TNM classification showed an adenocarcinoma, tubular pT3N1Mo stage IIIb. The resected specimen of renal cell carcinoma was clear cell renal cell carcinoma and pathologic classification according to the TNM classification showed pT1NoMx.

\section{DISCUSSION}

An aging society will result more often in patients with two or more concurrent cancers. The common sites with simultaneous presentation of CRC and other cancer in men are stomach, lung and prostate for men (43.8\%, $15.3 \%, 9.6 \%$ respectively), while in females are mammary, uterus, and stomach (32.4\%, 25.5\%, 19.3\% respectively). The synchrony of CRC and renal cell carcinoma is about $0.03-4.85 \%[3,4]$.

In this report we describe a combined laparoscopic approach to removing a synchronous CRC and renal cell cancer. This approach has several benefits that include utilize the same trocars that the urologists use which reduces the number of wounds and lessens postoperative pain and two operations were performed at the same time. Especially for elderly people, it is a matter of course that fewer operations are less stressful for patients. In addition, it reduces the total length of the wound. Thus, it has excellent esthetic outcome. On the other hand, there is drawback to doing one-stage surgery.

Gastrointestinal surgeries have a high risk of infections, whereas the urological surgeries are almost all clean operations. The mixture of infected and clean operations is subadequate. In this case, we performed the CRC operation at first, because the urologists were not able to attend the operation from the start. Considering the relative infection risk, it is better to start with the urology' operation. Another reason for the merit of preceding urologist's operation is the safety of the colon. Especially, the surgery for ipsilateral colon and kidney, cutting the ureter first makes it easier to do colon surgery.

We searched the literature for simultaneous laparoscopic resection of concurrent CRC and renal carcinoma and found 11 articles. [6-16] Results are summarized in Table 1 . The median of operative time

Table 1: Summarization of the case-studies with simultaneous laparoscopic resection of concurrent CRC and renal carcinoma.

\begin{tabular}{|c|c|c|c|c|c|}
\hline Author & Patient & Disease & $\begin{array}{l}\text { Operation } \\
\text { time }\end{array}$ & Blood loss & Pathology \\
\hline Napolitano et al. 2005 & 74-year-old male & $\begin{array}{l}\text { Left kidney, sigmoid } \\
\text { colon }\end{array}$ & $270 \mathrm{~min}$ & $300 \mathrm{ml}$ & RCC, ac \\
\hline Fazzin et al. 2013 & 79-year-old female & $\begin{array}{l}\text { Right kidney, bilateral } \\
\text { colon }\end{array}$ & N.A. & N.A. & $\begin{array}{l}\text { CCC, ac(sigmoid) adenoma } \\
\text { (right colon) }\end{array}$ \\
\hline Sullivan et al. 2015 & 73-year-old male & $\begin{array}{l}\text { Left kidney, sigmoid } \\
\text { colon }\end{array}$ & N.A. & N.A. & $\mathrm{RCC}, \mathrm{ac}$ \\
\hline Veenstra et al. 2011 & 70-year-old female & $\begin{array}{l}\text { Left kidney, ascending } \\
\text { colon }\end{array}$ & $210 \mathrm{~min}$ & $100 \mathrm{ml}$ & $\mathrm{CCC}, \mathrm{ac}$ \\
\hline Takahashi et al. 2014 & 70-year-old female & $\begin{array}{l}\text { Right kidney, } \\
\text { ascending colon }\end{array}$ & $450 \mathrm{~min}$ & $60 \mathrm{ml}$ & $\mathrm{CCC}, \mathrm{ac}$ \\
\hline Arnau et al. 2015 & 63-year-old male & $\begin{array}{l}\text { Left kidney, sigmoid } \\
\text { colon }\end{array}$ & $300 \mathrm{~min}$ & $\mathrm{o} \mathrm{ml}$ & Papillary RCC, ac \\
\hline Arnau et al. 2015 & 67-year-old male & $\begin{array}{l}\text { Right and left kidney, } \\
\text { sigmoid colon }\end{array}$ & $420 \mathrm{~min}$ & $900 \mathrm{ml}$ & $\begin{array}{l}\text { Cystic RCC (left), CCC (right), } \\
\text { ac }\end{array}$ \\
\hline Arnau et al. 2015 & 71-year-old male & Left kidney, rectal & N.A. & N.A. & Papillary RCC, ac \\
\hline Our case & 83-year-old male & Left kidney, cecal colon & $560 \mathrm{~min}$ & $30 \mathrm{ml}$ & $\begin{array}{l}\text { CCC, as } \\
\text { CCC: clear cell carcinoma } \\
\text { RCC: renal cell carcinoma } \\
\text { ac: adenocarcinoma }\end{array}$ \\
\hline
\end{tabular}




\section{EDORIUM Journals}

was 300-420 min and median of blood loss was 60$100 \mathrm{ml}$. 4 of the 9 was combined left-side and right-side laparoscopic procedure. Almost all of the patients were in their 60's or 70's. However, our case was 83-year-old (the oldest case reported). Our operation was a combined left-side and right-side laparoscopic procedure; 4 of the 9 reported cases were as well. Operation details were written for 9 of the 11 cases and all 9 indicated the potential of laparoscopic surgery. This case report highlights the benefit of operation with regard to treatment of two neoplasms at same time as well as reduction in the medical cost. One-stage surgery reduces the total medical cost [4].

\section{CONCLUSION}

Laparoscopic surgery for concurrent renal cell carcinoma and $\mathrm{CRC}$ is feasible and safe in elderly patients.

\section{REFERENCES}

1. Torre LA, Bray F, Siegel RL, Ferlay J, Lortet-Tieulent J, Jemal A. Global cancer statistics, 2012. CA Cancer J Clin 2015 Mar;65(2):87-108.

2. Ferlay J, Shin HR, Bray F, Mathers C, Parkin DM. GLOBOCAN 2008 Cancer Incidence and Mortality Worldwide: IARC CancerBase No. 10. Volume 1-2. Lyon, France: International Agency for Research on Cancer; 2010. [Available at: http://globocan.iarc.fr]

3. Halak M, Hazzan D, Kovacs Z, Shiloni E. Synchronous colorectal and renal carcinomas: A noteworthy clinical entity. Report of five cases. Dis Colon Rectum 2000 Sep;43(9):1314-5.

4. Capra F, Scintu F, Zorcolo L, Marongiu L, Casula G. Synchronous colorectal and renal carcinomas. Is it a definite clinical entity? Chir Ital 2003 NovDec;55(6):903-6.

5. Calderwood AH, Huo D, Rubin DT. Association between colorectal cancer and urologic cancers. Arch Intern Med 2008 May 12;168(9):1003-9.

6. Kim SH, Park JY, Joh YG, Hoe HE. Simultaneous laparoscopic radical nephrectomy and laparoscopic sigmoidectomy for synchronous renal cell carcinoma and colonic adenocarcinoma. J Laparoendosc Adv Surg Tech A 2004 Jun;14(3):179-81.

7. Napolitano C, Santoro GA, Valvano L, Salvati V, Martorano M. Simultaneous totally laparoscopic radical nephrectomy and laparoscopic left hemicolectomy for synchronous renal and sigmoid colon carcinoma: Report of a case. Int J Colorectal Dis 2006 Jan;21(1):92-3.

8. Ng SS, Yiu RY, Li JC, Chan CK, Ng CF, Lau JY. Endolaparoscopic left hemicolectomy and synchronous laparoscopic radical nephrectomy for obstructive carcinoma of the descending colon and renal cell carcinoma. J Laparoendosc Adv Surg Tech A 2006 Jun;16(3):297-300.

9. Ng SS, Lee JF, Yiu RY, Li JC, Leung KL. Synchronous laparoscopic resection of colorectal and renal/adrenal neoplasms. Surg Laparosc Endosc Percutan Tech 2007 Aug;17(4):283-6.

10. Nishiyama N, Yamamoto S, Matsuoka N, Fujimoto $\mathrm{H}$, Moriya Y. Simultaneous laparoscopic descending colectomy and nephroureterectomy for descending colon carcinoma and left ureteral carcinoma: Report of a case. Surg Today 2009;39(8):728-32.

11. Veenstra GM, Fossion LM, de Laet K, Luijten AA. Synchronous laparoscopic radical nephrectomy left and contralateral right hemicolectomy during the same endoscopic procedure. ISRN Surg 2011;2011:179456.

12. Martin Arnau AB, Ochoa Vargas C, Peña Gonzalez JA, Targarona Soler EM. Simultaneous colectomy and nephectomy in synchronic tumours. [Article in English, Spanish]. Cir Esp 2015 Apr;93(4):266-8. doi: 10.1016/j.ciresp.2014.04.006

13. Luca C, Federico C, Marco L, et al. Simultaneous laparoscopic nephrectomy and colectomy for synchronous primary malignancies: Surgical techniques and the results of two cases. Universal Journal of Clinical Medicine 2013;1(3):35-8.

14. Fazzin M, Dellachiesa L, Resta G, Bandi M, Marino $\mathrm{S}$, Anania G. One-stage laparoscopic procedure for a patient with bilateral colorectal tumours and renal carcinoma. G Chir 2013 Apr;34(4):132-4.

15. O’Sullivan M, Kearney DE, Giri SK, Coffey JC. Combined laparoscopic-assisted nephrectomy and complete mesocolic excision for synchronous renal and colon cancers. BMJ Case Rep 2015 Sep 29;2015. pii: bcr2015211681.

16. Takahashi M, Ichikawa R, Honjo K, et al. Simultaneous laparoscopic colectomy and nephrectomy for synchronous ascending colon cancer and right kidney cancer: Report of a case. Juntendo Medical Journal $2014 ; 60(4): 345^{-8 .}$

$* * * * * * * * *$

\section{Author Contributions}

Satoshi Tokuda - Substantial contributions to conception and design, Acquisition of data, Analysis and interpretation of data, Drafting the article, Revising it critically for important intellectual content, Final approval of the version to be published

Hajime Orita - Substantial contributions to conception and design, Acquisition of data, Analysis and interpretation of data, Drafting the article, Revising it critically for important intellectual content, Final approval of the version to be published

Hiroshi Maekawa - Substantial contributions to conception and design, Acquisition of data, Analysis and interpretation of data, Drafting the article, Revising it critically for important intellectual content, Final approval of the version to be published

Kentaro Imaizumi - Substantial contributions to conception and design, Acquisition of data, Analysis and interpretation of data, Drafting the article, Revising it critically for important intellectual content, Final approval of the version to be published

Kazuhiko Fujita - Substantial contributions to conception and design, Acquisition of data, Analysis 
www.ijcasereportsandimages.com

and interpretation of data, Drafting the article, Revising it critically for important intellectual content, Final approval of the version to be published

Koichi Sato - Substantial contributions to conception and design, Acquisition of data, Analysis and interpretation of data, Drafting the article, Revising it critically for important intellectual content, Final approval of the version to be published

\section{Guarantor of Submission}

The corresponding author is the guarantor of submission.

\section{Source of Support}

None

\section{Consent Statement}

Written informed consent was obtained from the patient for publication of this case report.

\section{Conflict of Interest}

Authors declare no conflict of interest.

\section{Copyright}

(C) 2018 Satoshi Tokuda et al. This article is distributed under the terms of Creative Commons Attribution License which permits unrestricted use, distribution and reproduction in any medium provided the original author(s) and original publisher are properly credited. Please see the copyright policy on the journal website for more information.
Access full text article on other devices

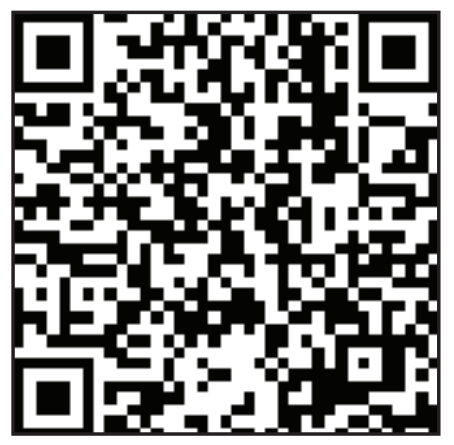

Access PDF of article on other devices

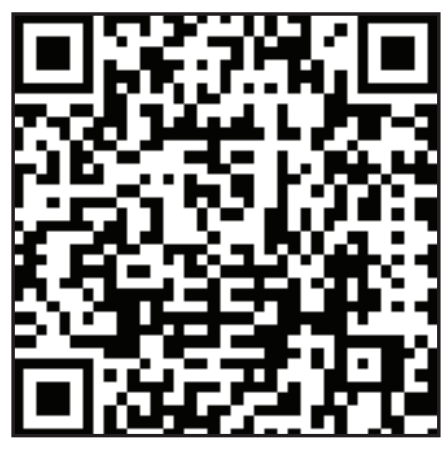

